precedes the splitting up of a species into others, and so this extent we may feel that we are witnessing in Achillea not micro-evolution only (to use the name coined by Goldschmidt) but a phase of macroevolution also. That it is a phase only and not necessarily the whole story of macro-evolution the authors themselves would probably be the first to admit. The facts so far ascertained for Achillea are, however, a salutary reminder that evolutionary trends are not wholly directed by factors internal to the organism, as some evolutionists, in reaction against simple Darwinism, have recently tended to think, and for this purpose alone, therefore, this work merits close attention.

I. MANTON

$H=$

\section{TREASURY GRANTS FOR SCIENCE AND RESEARCH IN GREAT BRITAIN}

A MONG the items of interest to scientific workers $A$ in the Civil Estimates for 1949-50, Class I, Central Governf $£ 32,625$ fon the Central Economic Planning Staff, the staff of whish is reduced from 28 to 24 , and $£ 23,787$ for the Economic Information Unit, the staff of which is increased from 13 to 22 . The Organisation and Methods Division of the Treasury has also been expanded with a staff of 79 as against 57 in the previous year and with a vote of $£ 71,706$ in place of $\{51,733$.

For the Government Chemist $£ 188,061$ is required, an increase of $£ 16,333$, while the estimate for the Office of the Lord President of the Council is practically unchanged at $\$ 19,200$, in spite of an increase of 4 in the scientific staff. The Estimates for Class IV (Education and Broadcasting) include $£ 144,091$ for the Science Museum as against $£ 132,443$ in $1948-49$, $\{275,712$ for the British Museum, a net decrease of $£ 8,215, £ 215,315$ for the British Museum (Natural History), a net increase of $£ 17,666$, and $£ 14,150,000$ for broadcasting, a net increase of $£ 450,000$. Estimates of $£ 3,370,868$ for science and the arts include $£ 43,500$ for the Royal Society ( $£ 20,000$ for scientific investigations and $£ 17,250$ for scientific publications), $£ 40,500$ for the National Library and $£ 41,000$ for the National Museum of Wales, $£ 22,500$ for the National Central Library, $\mathfrak{1 1 , 6 1 8 , 0 0 0}$ for the Medical Research Council, of which $£ 369,000$, or the bulk of the increase of $£ 483,000$, is for the erection and structural adaptation of buildings and the purchase of special equipment, including a cyclotron, $£ 777,000$ for the Agricultural Research Council (an increase of $£ 327,000), £ 100,000$ for Nature Conservancy, $£ 575,000$ for the Arts Council of Great Britain and $£ 46,000$ for the British Film Institute. With $£ 2,000$ for the Royal Society of Edinburgh and $£ 3,000$ for the Solar Physics Observatory the estimates for research and development under Class IV, Science and the Arts section, amount to $£ 2,543,500$.

An appendix to the Estimates sets forth the other amounts provided for research and development in the Estimates for $1949-50$ and totalling $£ 96,072,533$. This includes $£ 6,632,000$ for scientific services in the Navy Estimates, as well as $£ 2,758,000$ under shipbuilding repairs, maintenance, etc., and $£ 481,000$ under Works, Building and Repairs at Home and Abroad. Under Class II, there are $£ 35,765$ for
Commonwealth Economic and Research Services, $£ 10,000$ for the National Institute of Oceanography, and $£ 950,000$ for Development and Welfare (Colonies, etc.) Research Schemes. Research and testing under the Ministry of Fuel and Power are estimated at $£ 226,600$, while Class VI also includes $£ 1,240,970$ for agricultural, fishery and shell-fish research, $£ 139,300$ for forestry research, and $£ 424,807$ for the Development Fund. For the Department of Scientific and Industrial Research the net amount is $f 4,199,625$, and for agricultural research under the Department of Agriculture for Scotland, $£ 500,021$. Under the Ministry of Works, the estimate for scientific and research establishments, etc., amounts to $£ 918,685$, and miscellaneous items bring an estimate of $£ 54,800,000$ for research and development under the Ministry of Supply to a total of $£ 74,473,000$.

For the Universities and Colleges, etc., of Great Britain, $£ 17,671,500$, an increase of $£ 5,168,500$, is provided, including a loan of $£ 75,000$ for housing accommodation for staff and $£ 32,000$ for postgraduate studentships in Oriental, Slavonic, East European and African studies. Non-recurrent grants represent $£ 4,750,000$, and of the remainder $£ 8,482,853$ is for English Universities, $£ 504,200$ for Wales and $£ 1,538,537$ for Scottish Universities. In addition to those grants made on the recommendation of the University Grants Committee, there are a number of grants for specific purposes made to individual universities by different Departments or bodies, and these are given in an appended schedule.

\section{FORTHCOMING EVENTS}

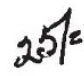

(Meeting marked with an asterisk * is open to the public)

\section{Monday, April II}

MANCHESTRR LTTERART AND PHILOSOPHICAL SOCIETY (in the Reynolds Hall, ollege of Technology, Manchester), at 5.30 p.m.Mr. R. F T T. T.

Ro SAx GEOORAPHICAL SOCIETY (at Kensington Gore, London, S.W.7) at 5.30 p.m. "North-West Tran To-day" (Kodachrome films with commentary by Sir Clarmont Skrine).

NORTH-EAST COAST INSTITUTTON OF ENGINEERS AND SHIPBUILDERS (in the Mining Institute, Newcastle-upon-Tyne), at 6 p.m.-Mr. W. Muckle : "Experiments on a Light Alloy Model Superstructure"."

INSTITUTION OF ELECTRICAL ENGINGHRS, EDUCATION DISCUSSION CIROLE (at Savoy Place, Victoria Embankment, London, w.C.2), at 6 p.m.-Discussion on "The Scheme for the Interchange of Information on Electrical Encineering Laboratory Practice" (to be opened by Dr. F. Bradshaw) and "Transient Display Apparatus" (to be opened by Mr. A. C. Normington).

\section{Tuesday, April 12}

ROYAL SOCIETY OF ARTS, DOMINIONS AND COLONIES SECTION (at John Adam Street, Adelphi, London, W.C.2), at 2.30 p.m.-Sir Frank Stockdale, G.C.M.G.: "Colonial Development".

Societr of Chemian Industry, Plastics Grodp (at the Royal Society of Tropical Medicine, Manson House, 26 Portland Place, London, W.1), at 2.30 p.m.-Dr. W. C. Fergusson: "Polytetrafluorethylene",

ZoOLOGICAI SoOIETY of LONDON (at the Zoological Gardens, Regent's Park, London, N.W.8), at 5 p.m.--Scientifle Papers.

INSTITUTION OP ELECTRIOAL ENGINEERS, RADIO SECTION (at Savoy Place, Victoria Embankment, London, W.C.2), at 5.30 p.m.-Dr. R. H. Barfield: "Radio-Frequency Heating".

Institution of MECHanical EngineERs (at Storey's Gate, St. James's Park, London S.W.1), at 6 p.m-Mr. H. R. Mills and Mr. James's Park, London, S.W.1), at 6 p.m.-Mr. H. R. Mills
R. J. Love : "The Fatigue Strength of Cast Crankshafts".

Manchester Grographicax Society (in the Geographical Hall, St. Mary's Parsonage, Manchester), at 6.30 p.m.-Mrs. E. D. Pugh "In and Around Madras".

Sheffield Metaludraical Association (at 198 West Street, Sheffield), at 7 p.m.-Dr. G. R. Davies: "Chromatography".

SOCIETY OF INSTRUMENT TECHNOLOGY, NORTH-WEST SRCTION (at the College of Technology, Manchester), at 7.30 p.m.-Mr. D. O. Walter: "Some Metals and Alloys for the Instrument Designer". 